\title{
Saliva as a tool for monitoring hemodialysis: a systematic review and meta-analysis
}

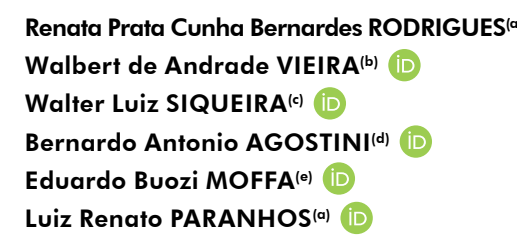

(a) Universidade Federal de Uberlândia UFU, School of Dentistry, Department of Preventive and Community Dentistry, Uberlândia, MG, Brazil.

(b) Universidade Estadual de Campinas Unicamp, School of Dentistry of Piracicaba, Department of Restorative Dentistry, Endodontics Division, Piracicaba, SP, Brazil.

(c) University of Saskatchewan, College of Dentistry, Saskatoon, SK, Canada.

(d)Faculdade Meridional - IMED, Department of Dentistry, Passo Fundo, RS, Brazil.

(e) Centro Universitário das Faculdades Associadas - Unifae, Department of Dentistry, São João da Boa Vista, SP, Brazil.

Declaration of Interests: The authors certify that they have no commercial or associative interest that represents a conflict of interest in connection with the manuscript.

\section{Corresponding Author:}

Luiz Renato Paranhos

E-mail: paranhos.Irp@gmail.com

Submitted: December 8, 2019

Accepted for publication: September 1, 2020

Last revision: September 21, 2020
Abstract: This study aimed to assess whether the reductions in serum urea and creatinine levels are different from the reductions in salivary urea and creatinine levels that occur after hemodialysis in chronic renal patients. The systematic review protocol was registered in the PROSPERO database. Eight databases were searched to identify pretest-posttest studies of chronic kidney disease patients undergoing hemodialysis, with no language or year restrictions. The JBI Critical Appraisal Tool was used to assess the risk of bias. Meta-analyses using random-effect models were conducted to compare salivary and serum correlations and to pooled mean and proportion differences from preto posthemodialysis urea and creatinine levels by subgroup analysis. The $\mathrm{I}^{2}$ test was used to assess heterogeneity, and a meta-regression was performed to statistically assess correlations and differences in the pooled effects pre- and postdialysis. The Grading of Recommendation, Assessment, Development, and Evaluation (GRADE) was used to assess the certainty of evidence. The search resulted in 1404 records, and only six studies ( $\mathrm{n}=252$ participants) fulfilled the eligibility criteria and were included. The studies were published between 2013 and 2018. All studies showed a significant reduction in both salivary and serum urea/ creatinine levels. All eligible studies presented a low risk of bias. The meta-analysis shows a moderate to high correlation between salivary and blood levels of urea (r: 0.79; 95\% CI: 0.56-1.00) and creatinine (r: 0.64; 95\%CI: $0.16-1.00)$, with a very low level of certainty. The reductions in salivary urea and creatinine levels are similar to and correlated with the reductions in blood urea and creatine levels after hemodialysis among chronic kidney disease patients.

Keywords: Renal Insufficiency, Chronic; Saliva; Urea; Creatinine.

\section{Introduction}

Hemodialysis is the treatment option commonly indicated for purifying blood in patients diagnosed with advanced chronic kidney disease (CKD). ${ }^{1}$ Hemodialysis is responsible for filtering toxic substrates from the bloodstream, such as creatinine, urea, and phosphorus, thus decreasing the signs and symptoms of these patients. ${ }^{2}$

The glomerular filtration rate (GFR) is an assessment of the filtering capacity of the functioning nephrons in the kidneys. GRF is a sensitive 
method to detect and monitor changes in renal function. ${ }^{3}$ Changes in GFR are a good predictor for determining the need for renal replacement therapy such as dialysis. The clearance of exogenous substances such as inulin or various radiolabeled markers is considered the gold standard for determining GFR. In addition, despite the use of creatinine and urea levels, cystatin $\mathrm{C}$ has been considered a candidate marker to evaluate patients with CDK, and interestingly, this protein can also be found and precisely quantified in saliva using state-of-the-art mass spectrometry. Monitoring the efficacy of hemodialysis is of utmost importance for determining the clinical prognosis of the patient and for follow-up on regression or the development of renal failure. ${ }^{4}$ Laboratory analysis of blood is used to identify substrates in the blood, such as creatinine and urea. ${ }^{5}$ However, blood collection is an invasive procedure that may lead some patients into a state of anxiety. ${ }^{6}$ Moreover, repeated venous punctures increase the chances of infection, which explains why CKD patients present higher risks of infection from hepatitis B and C.?

The collection of saliva has been presented as an excellent alternative to collecting blood, considering that saliva is an alternative for the presence of bioproducts containing several blood serum components. ${ }^{8}$ Recent studies have presented promising results regarding the correlation of saliva and blood analytes in different clinical conditions. ${ }^{9,10,11}$ Specifically, for chronic kidney disease, saliva has been shown to be a promising tool for diagnosing this condition in early stages. ${ }^{12}$ Thus, this easy collection procedure is a noninvasive and low-cost method, making saliva an optimum fluid for monitoring hemodialysis effects from home. ${ }^{6}$

In this context, the present systematic review aims to assess whether changes in the levels of urea and creatinine that occur in the serum will also occur in saliva after hemodialysis in patients diagnosed with chronic kidney disease.

\section{Methodology}

\section{Protocol and registration}

This systematic review was performed in accordance with the Preferred Reporting Items for
Systematic Reviews and Meta-Analyses (PRISMA) recommendations ${ }^{13}$ and the Joanna Briggs Institute Manual. ${ }^{14}$ The systematic review protocol was registered in the PROSPERO database (CRD42018116775).

\section{Research question and eligibility criteria}

The performance of the study was supported by the following research question: "Is there a correlation between salivary and serum urea and creatinine levels after hemodialysis in chronic renal patients?"

\section{Inclusion criteria}

a. Population: Adult patients ( $>18$ years old) with end-stage $\mathrm{CKD}$ (glomerulation filtration rate $<15 \mathrm{~mL} / \mathrm{min} / 1.73 \mathrm{~m}^{2}$ ) undergoing hemodialysis treatment.

b. Intervention: Salivary analysis.

c. Comparator: Serum analysis.

d. Outcome: Assessment of urea and creatinine levels after hemodialysis.

e. Study design: Clinical studies of pretestposttest design with or without healthy patients as a control group to observe both salivary and blood levels of urea and creatinine preand posthemodialysis, with no restrictions on language or year of publication.

\section{Exclusion criteria}

a. Review articles, letters to the editor/editorials, personal opinions, books/book chapters, textbooks, reports, conference abstracts, and patents.

b. Studies including patients with other kidney diseases in addition to CKD;

c. Studies with pediatric patients.

\section{Sources of information and search}

The Embase, Latin-American and Caribbean Health Sciences Literature (LILACS), PubMed/MEDLINE, SciELO, Scopus, and Web of Science databases were used as primary study sources. OpenThesis and OpenGrey were used to partially search the "grey literature". Additionally, the reference lists of the eligible studies were manually searched to obtain additional studies. All steps were performed to minimize study selection bias. 
The Medical Subject Heading (MeSH) terms, Health Sciences Descriptors (DeCS), and Embase Subject Headings (Emtree) resources were used to select the search descriptors. In addition, synonyms and free terms were used to enhance the search. The Boolean operators "AND" and "OR" were used to enhance the search strategy through several combinations according to each database. The search terms and strategy were adapted for each database (Table 1). The bibliographic research was performed in December 2018 and updated on March 21st, 2020.
The results obtained were exported to EndNote Web ${ }^{\mathrm{TM}}$ software (Thomson Reuters, Toronto, Canada), in which duplicates were removed automatically. The remaining results were exported to Microsoft Word ${ }^{\mathrm{TM}}$ 2010 (Microsoft $^{\mathrm{TM}}$ Ltd, Washington, USA), in which any remaining duplicates were removed manually.

\section{Study selection}

The studies were selected in three phases. In the first phase, as a calibration exercise, the reviewers discussed the eligibility criteria and applied them to

Table 1. Strategies for database search.

\begin{tabular}{|c|c|}
\hline Database & Search Strategy (March, 2020) \\
\hline $\begin{array}{l}\text { PubMed } \\
\text { http://www.ncbi.nlm.nih.gov/pubmed }\end{array}$ & $\begin{array}{l}\text { ("Kidney Diseases" OR "Kidney Disease" OR "Chronic Kidney Disease" OR “Chronic Renal } \\
\text { Disease" OR "Renal Insufficiencies" OR "Kidney Insufficiency" OR "Renal Function" OR “Kidney } \\
\text { Function" OR "Renal Failure" OR "Renal Injury") AND ("Saliva" OR "Salivary Creatine" OR } \\
\text { "Salivary Urea" OR "Salivary Biomarkers") }\end{array}$ \\
\hline $\begin{array}{l}\text { Scopus } \\
\text { hHp://www.scopus.com/ }\end{array}$ & $\begin{array}{c}\text { ( ("Kidney Diseases" OR "Kidney Disease" OR "Chronic Kidney Disease" OR "Chronic Renal } \\
\text { Disease") AND ("Saliva" OR "Salivary Creatine" OR "Salivary Urea") ) }\end{array}$ \\
\hline LILACS & tw:("Kidney Diseases" AND "Saliva") AND (instance:"regional”) AND (db:(“LILACS")) \\
\hline \multirow[t]{5}{*}{ hHp://lilacs.bvsalud.org/ } & tw:(“Renal Insufficiencies” AND “Saliva”) AND (instance:"regional”) AND (db:(“LILACS”)) \\
\hline & tw:(“Kidney Insufficiency" AND “Saliva”) AND (instance:"regional”) AND (db:(“LILACS")) \\
\hline & tw:(“Kidney Diseases" AND “Salivary Creatine”) AND (instance:"regional”) AND (db:(“LILACS”)) \\
\hline & $\begin{array}{c}\text { tw: (“Renal Insufficiencies" AND "Salivary Creatine”) AND (instance:"regional”) AND } \\
(\text { db:(“LILACS")) }\end{array}$ \\
\hline & tw:(“Kidney Diseases" AND “Salivary Urea") AND (instance:"regional”) AND (db:(“LILACS”)) \\
\hline SciELO & Kidney Diseases AND Saliva \\
\hline \multirow[t]{8}{*}{ http://www.scielo.org/ } & Renal Insufficiencies AND Saliva \\
\hline & Kidney Insufficiency AND Saliva \\
\hline & Kidney Diseases AND Salivary Creatine \\
\hline & Hemodialíse AND Saliva \\
\hline & Kidney Insufficiency AND Salivary Creatine \\
\hline & Kidney Diseases AND Salivary Urea \\
\hline & Renal Insufficiencies AND Salivary Urea \\
\hline & Kidney Insufficiency AND Salivary Urea \\
\hline $\begin{array}{l}\text { Embase } \\
\text { http://www.embase.com }\end{array}$ & $\begin{array}{l}\text { ('kidney diseases' OR 'kidney disease' OR 'chronic kidney disease' OR 'chronic renal disease' } \\
\text { OR 'renal insufficiencies' OR 'kidney insufficiency' OR 'renal function' OR 'kidney function' } \\
\text { OR 'renal failure' OR 'renal injury') AND ('saliva' OR 'salivary creatine' OR 'salivary urea' OR } \\
\text { 'salivary biomarkers') }\end{array}$ \\
\hline $\begin{array}{l}\text { Web Of Science } \\
\text { http://apps.webofknowledge.com/ }\end{array}$ & $\begin{array}{c}\text { (( "Kidney Diseases" OR "Kidney Disease" OR "Chronic Kidney Disease" OR “Chronic Renal } \\
\text { Disease" OR "Renal Insufficiencies" OR "Kidney Insufficiency" OR "Renal Function" ) AND } \\
\text { ("Saliva" OR "Salivary Creatine" OR "Salivary Urea" )) }\end{array}$ \\
\hline $\begin{array}{l}\text { OpenGrey } \\
\text { http://www.opengrey.eu/ }\end{array}$ & $\begin{array}{c}\text { ( "Kidney Diseases" OR "Kidney Disease" OR “Chronic Kidney Disease" OR "Chronic Renal } \\
\text { Disease" OR "Renal Insufficiencies" OR "Kidney Insufficiency" OR "Renal Function" ) AND } \\
\text { ("Saliva" OR "Salivary Creatine" OR "Salivary Urea") }\end{array}$ \\
\hline $\begin{array}{l}\text { OpenThesis } \\
\text { http://www.openthesis.org/ }\end{array}$ & ("Kidney Disease") AND ("Saliva") \\
\hline
\end{tabular}


a sample of $20 \%$ of the studies retrieved to determine the interexaminer agreement. After achieving a proper level of agreement (Kappa $\geq 0.81$ ), two eligibility reviewers (RPCBR and WAV) methodically analyzed the titles of the studies independently. The reviewers were not blind to the names of authors and journals. Titles not related to the topic were eliminated in this phase. In the second phase, the reviewers (RPCBR and WAV) read the abstracts independently for the initial application of the aforementioned exclusion criteria. Those results with titles that met the objectives of the study but did not have abstracts available were fully analyzed in phase three.

In the third phase, the preliminary eligible studies had their full texts obtained and evaluated to verify whether they fulfilled the eligibility criteria. When reviewers disagreed, a third reviewer (LRP) was consulted to make a final decision. The studies rejected in this phase were registered separately, and the reasons for exclusion were specified.

\section{Data collection}

The following information was extracted from the studies selected: study identification (author, year, location), sample characteristics (number of patients in each study, distribution by sex, average age), sample collection and processing characteristics (saliva collection method, collection time of the biological material, type of salivary and blood analysis, type of statistical analysis), and specific results (concentrations of salivary and blood urea, concentrations of salivary and blood creatinine, percentage of posthemodialysis reduction, main conclusions). In case of incomplete or insufficient information, the corresponding author was contacted via e-mail. There were no language restrictions, but articles in languages other than English or Portuguese were translated to ensure that data were properly extracted.

To ensure consistency among reviewers, training was performed with both reviewers, in which information was extracted jointly from an eligible study. Disagreements between the reviewers were resolved through discussion and consensus. When this was not possible, a third reviewer (LRP) was consulted to make a final decision.

\section{Risk of individual bias of the studies}

The Joanna Briggs Institute Critical Appraisal Tools for use in JBI Systematic Reviews for quasiexperimental studies ${ }^{15}$ assessed the risk of bias and the individual quality of the studies selected. The tool for quasi-experimental studies was chosen because it addresses the evaluation of pretest-posttest studies where the participants are not randomized. ${ }^{16}$

Two authors (WAV and LRP) independently assessed each domain regarding their potential risk of bias, as recommended by the PRISMA statement. ${ }^{12}$ Any disagreement between the reviewers was solved through discussions on the topics assessed, and a third reviewer was consulted to make a final decision.

The risk of bias was ranked as high when the study reached $49 \%$ of the "yes" score, moderate when the study reached $50 \%$ to $69 \%$ of the "yes" score, and low when the study reached over $70 \%$ of the "yes" score.

\section{Summary measures and syntheses of results}

To summarize the data, a descriptive analysis of the findings was performed. The effectiveness of the salivary measure in comparison to serum values was evaluated using meta-analysis. To compare salivary and serum agreement, a meta-analysis was conducted of correlation according to correlation (r) values available for each study. Standard errors and confidence intervals $(95 \% \mathrm{CI})$ of correlation coefficients were estimated to perform the meta-analysis. To compare salivary and serum concentrations of urea and creatinine, a subgroup meta-analysis was conducted evaluating the pooled mean and proportion differences from pre- to posthemodialysis results. Only articles with data from salivary and serum concentrations were included in the meta-analysis of each renal function indicator to ensure proper comparison of pooled estimates using the same samples. The measures described in $\mathrm{mg} / \mathrm{dL}$ were converted to $\mathrm{mmol} / \mathrm{L}$ using the MediCalc tool (http://www.scymed.com/) to standardize the data. ${ }^{17}$ To compare salivary and serum concentrations of urea and creatinine on the same scale, the results of potential changes in the mean concentration were presented as a standard mean difference with Hedges correction $(\mathrm{g})$, and conversions were performed using the formulas presented by Borenstein et al. ${ }^{18}$ 
Additionally, a meta-regression was performed to statistically assess differences in the pooled effects estimated ( $g$; and proportion). The meta-analysis of all outcomes was performed using fixed- and random-effect models. The selection of each effect, either random or fixed, was based on the presence of heterogeneity $\left(\mathrm{p}<0.05\right.$, chi-square or $\left.\mathrm{I}^{2}>50 \%\right)$. When this occurred, the random effects model was preferred. ${ }^{19}$ Moreover, salivary and serum percentage reductions were measured for each renal function indicator, and the pooled effects were estimated.

\section{Certainty of evidence}

Certainty of evidence was assessed with the Grading of Recommendation, Assessment, Development, and Evaluation (GRADE) tool..$^{20}$ GRADE pro GDT software (http://gdt.guidelinedevelopment.org) was used to summarize the results. This assessment was based on study design, risk of bias, inconsistency, indirect evidence, imprecision, and other considerations. The certainty of evidence was characterized as high, moderate, low, or very low. ${ }^{20}$

\section{Results}

\section{Study selection}

During the first phase of study selection, 1,404 results were found distributed in eight electronic databases, including the grey literature. After removing the duplicates, 745 results remained for analysis of titles and abstracts. After applying eligibility criteria to the titles and abstracts, only eight results were eligible for full-text analysis. The references of the eight potentially eligible studies were carefully assessed, and one additional study was selected, resulting in nine studies for full-text reading. After reading the full text, the studies of Khanum et al., ${ }^{4}$ Suzuki et al. ${ }^{21}$ and Chen et al. ${ }^{22}$ were excluded for not performing blood analysis after hemodialysis. Thus, six studies ${ }^{23,24,25,26,27,28}$ were selected for the qualitative analysis. Figure 1 reproduces the process of search, identification, inclusion, and exclusion of articles.

\section{Characteristics of eligible studies}

The studies were published between 2013 and 2018 and were performed in China, ${ }^{23}$ India, ${ }^{24}$ Finland, ${ }^{25}$
Bulgaria, ${ }^{26}$ Italy, ${ }^{27}$ and Turkey. ${ }^{28}$ The total sample included 252 chronic kidney disease (CKD) patients undergoing hemodialysis. Only one study presented a control group with healthy participants $(n=40) .{ }^{28}$ The average age of the sample ranged from 43.9 to 60.66 . Men prevailed in all the eligible studies containing sex data.

Saliva and blood samples were collected simultaneously in five studies $23,24,26,27,28$ before and after hemodialysis. The study by Bilancio et al. ${ }^{26}$ also collected blood and saliva during hemodialysis. The collection of saliva samples was unstimulated in four studies ${ }^{23,25,26,27}$ and stimulated in two studies. ${ }^{23,25}$ Saliva and blood were analyzed with the colorimetric method in four eligible studies. ${ }^{23,24,25,26}$ The study by Chen et al. ${ }^{25}$ also observed the relationship between salivary urea concentration and ammonia in the breath of CKD patients. Table 2 shows detailed information about each eligible study.

\section{Specific results of the eligible studies}

All eligible studies ${ }^{23,24,25,26,27,28}$ assessed the levels of urea. In the saliva analysis predialysis, the concentration of urea ranged from $15.85 \mathrm{mmol} / \mathrm{L}$ to $46.89 \mathrm{mmol} / \mathrm{L}$, while in the saliva analysis postdialysis, the concentration ranged from $5.94 \mathrm{mmol} / \mathrm{L}$ to 46.78 $\mathrm{mmol} / \mathrm{L}$. The differences pre- and postdialysis ranged from $0.3 \%$ to $68 \%$. When blood was analyzed, urea ranged from $21.24 \mathrm{mmol} / \mathrm{L}$ to $43.9 \mathrm{mmol} / \mathrm{L}$ before dialysis and from $6.4 \mathrm{mmol} / \mathrm{L}$ to $14.8 \mathrm{mmol} / \mathrm{L}$ after dialysis. Three ${ }^{23,25,27}$ studies found a strong correlation between blood urea and salivary urea, and one study ${ }^{27}$ showed a moderate correlation. The other two studies ${ }^{23,25}$ did not perform correlation statistics (Table 3).

Four eligible studies ${ }^{23,24,26,28}$ assessed the levels of creatinine. In the saliva analysis predialysis, the concentration of creatinine ranged from $0.6363 \mathrm{mg} / \mathrm{dL}$ to $1.13 \mathrm{mg} / \mathrm{dL}$, while in the saliva analysis postdialysis, the concentration ranged from $0.34 \mathrm{mg} / \mathrm{dL}$ to $0.6343 \mathrm{mg} / \mathrm{dL}$. The differences pre- and postdialysis ranged from $0.4 \%$ to $70 \%$. When blood was analyzed, creatinine ranged from $7.24 \mathrm{mg} / \mathrm{dL}$ to $11.28 \mathrm{mg} / \mathrm{dL}$ before dialysis and from $2.99 \mathrm{mg} / \mathrm{dL}$ to $4.12 \mathrm{mg} / \mathrm{dL}$ after dialysis. The differences in blood creatinine pre- and postdialysis ranged from $31 \%$ 


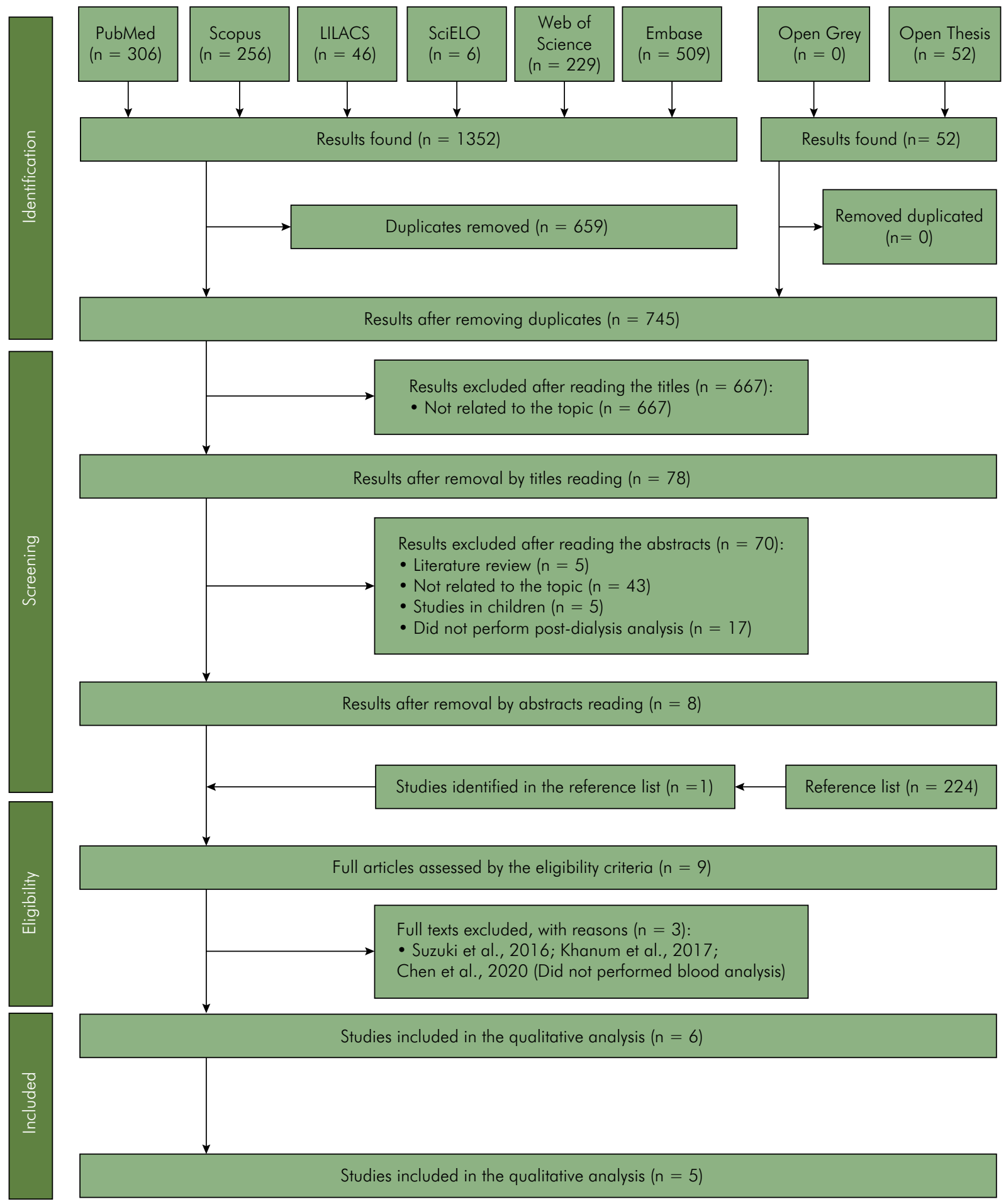

Figure 1. Flowchart of the literature search and selection process adapted from the PRISMA statement.

to $72 \%$. The differences in blood creatinine pre- and postdialysis ranged from $52 \%$ to $64 \%$. One study ${ }^{23}$ observed a strong correlation between serum and salivary creatinine, while one study ${ }^{28}$ found a low correlation. The other studies ${ }^{24,26}$ did not examine correlation coefficients (Table 4). 
Table 2. Summary of the main characteristics of the eligible studies.

\begin{tabular}{|c|c|c|c|c|c|c|c|}
\hline $\begin{array}{l}\text { Author, year, and } \\
\text { location }\end{array}$ & Sample (n) & $\begin{array}{l}\text { Mean age } \\
\text { in years } \\
\text { (SD) }\end{array}$ & $\begin{array}{l}\text { Saliva collection } \\
\text { method }\end{array}$ & $\begin{array}{l}\text { Time of blood } \\
\text { collection } \\
\text { relative to saliva } \\
\text { collection }\end{array}$ & $\begin{array}{c}\text { Type of salivary } \\
\text { analysis }\end{array}$ & $\begin{array}{l}\text { Type of blood } \\
\text { analysis }\end{array}$ & $\begin{array}{l}\text { Statistical } \\
\text { analysis }\end{array}$ \\
\hline $\begin{array}{l}\text { Cheng et al., } 2013 . \\
\text { China }^{23}\end{array}$ & 47 & $48.0(13.5)$ & $\begin{array}{l}\text { Stimulated saliva } \\
\text { was collected }(2 \mathrm{ml}) \\
\text { using the spitting } \\
\text { method before and } \\
\text { after dialysis. }\end{array}$ & Simultaneously & $\begin{array}{l}\text { Automatic } \\
\text { analyzer } \\
\text { (colorimetric } \\
\text { method). }\end{array}$ & $\begin{array}{l}\text { Automatic } \\
\text { analyzer } \\
\text { (colorimetric } \\
\text { method). }\end{array}$ & $\begin{array}{l}\text { Student's } \dagger \\
\text { test, paired } \\
\text { t test, and } \\
\text { Pearson's } \\
\text { correlation } \\
\text { analysis. }\end{array}$ \\
\hline $\begin{array}{l}\text { Seethalakshmi et al., } \\
\text { 2014. India }{ }^{24}\end{array}$ & (160 14ㅇ) & 50.33 & $\begin{array}{l}\text { Unstimulated whole } \\
\text { saliva was collected } \\
\text { (approximately } \\
5 \text { ml) using the } \\
\text { spitting method } \\
\text { before and after } \\
\text { dialysis. }\end{array}$ & Simultaneously & $\begin{array}{l}\text { Automatic } \\
\text { analyzer } \\
\text { (colorimetric } \\
\text { method). }\end{array}$ & $\begin{array}{l}\text { Automatic } \\
\text { analyzer } \\
\text { (colorimetric } \\
\text { method). }\end{array}$ & $\begin{array}{l}\text { Paired t test } \\
\text { analysis. }\end{array}$ \\
\hline $\begin{array}{l}\text { Chen et al., } 2016 . \\
\text { Finland } 25\end{array}$ & $\left(80^{\lambda} 4 q\right)$ & 52.41 & $\begin{array}{l}\text { Stimulated saliva } \\
\text { was collected } \\
\text { after } 1 \text { minute by } \\
\text { chewing a paraffin } \\
\text { pellet } 1 \text { minute } \\
\text { before, during, and } \\
\text { after dialysis. }\end{array}$ & Simultaneously & $\begin{array}{l}\text { Colorimetric } \\
\text { method. }\end{array}$ & $\begin{array}{c}\text { Photometric } \\
\text { enzymatic } \\
\text { method. }\end{array}$ & $\begin{array}{l}\text { Spearman's } \\
\text { rank } \\
\text { correlation } \\
\text { test. }\end{array}$ \\
\hline $\begin{array}{l}\text { Alpdemir et al., } \\
\text { 2018. Turkey }\end{array}$ & 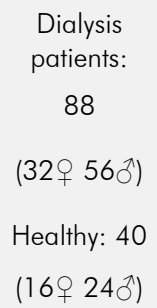 & $\begin{array}{l}\text { Dialysis } \\
\text { patients: } \\
45.8 \text { (13.3) } \\
\text { Healthy: } \\
43.9(8.5)\end{array}$ & $\begin{array}{l}\text { Unstimulated saliva } \\
\text { was collected using } \\
\text { the spitting method } \\
\text { after } 5 \text { min of } \\
\text { relaxation. }\end{array}$ & Simultaneously & $\begin{array}{l}\text { Spectrophotometric } \\
\text { method. }\end{array}$ & $\begin{array}{l}\text { Spectrophotometric } \\
\text { method. }\end{array}$ & $\begin{array}{l}\text { Student's } \dagger \\
\text { test, paired } \\
\text { t test, and } \\
\text { Pearson's } \\
\text { correlation } \\
\text { analysis. }\end{array}$ \\
\hline $\begin{array}{l}\text { Bilancio et al., } 2018 . \\
\text { Italy }\end{array}$ & 5 & * & $\begin{array}{l}\text { Saliva samples } \\
\text { were collected } \\
\text { using a synthetic } \\
\text { swap (Salivette, } \\
\text { Sarstedt, Germany). }\end{array}$ & $\begin{array}{l}1-2 \text { minutes } \\
\text { before }\end{array}$ & $\begin{array}{l}\text { Urease/NADH } \\
\text { method for urea. }\end{array}$ & $\begin{array}{l}\text { Automated } \\
\text { biochemistry and } \\
\text { commercially } \\
\text { available kits. }\end{array}$ & $\begin{array}{l}\text { Student's } \dagger \\
\text { test, simple } \\
\text { correlation } \\
\text { coefficient, } \\
\text { and linear } \\
\text { regression. }\end{array}$ \\
\hline $\begin{array}{l}\text { Nogalcheva et al., } \\
2018 \text {. Bulgaria } 26\end{array}$ & $\begin{array}{c}70(32 \text { ) } \\
380^{7}\end{array}$ & $\begin{array}{c}60.66 \\
(14.46)\end{array}$ & $\begin{array}{l}\text { The subjects were } \\
\text { instructed to spit } \\
\text { saliva every minute } \\
\text { for approximately } \\
5 \text { minutes without } \\
\text { causing prior } \\
\text { stimulation of the } \\
\text { salivary secretion. }\end{array}$ & Simultaneously & $\begin{array}{l}\text { UV kinetic } \\
\text { method for urea } \\
\text { and colorimetric } \\
\text { method for } \\
\text { creatinine. }\end{array}$ & $\begin{array}{l}\text { UV kinetic } \\
\text { method for urea } \\
\text { and colorimetric } \\
\text { method for } \\
\text { creatinine. }\end{array}$ & $\begin{array}{c}\text { Descriptive } \\
\text { statistics, Phi } \\
\text { and Cramer's } \\
\text { V nominal } \\
\text { associations, } \\
\text { and Pearson's } \\
\text { chi-square } \\
\text { test. }\end{array}$ \\
\hline
\end{tabular}

*Not cited by the authors.

\section{Risk of individual bias of the studies}

All eligible studies ${ }^{23,24,25,26,27,28}$ presented a low risk of bias. Item 4 was considered ' $N o$ ' for four eligible studies $^{23,24,25,26}$ due to lack of a control group. Item 5 was considered 'Uncertain' for all studies because they did not make it clear how many pre-posttest measurements were performed. . $3,24,25,26,27,28$ Item 6 was considered 'Not Applicable' for all studies ${ }^{23,24,25,26,27,28}$ because the posttests were performed immediately after hemodialysis, with no follow-up. Table 5 shows detailed information on the risk of bias of the studies included.

Q1. Is it clear in the study what is the 'cause' and what is the 'effect' (i.e., there is no confusion about which variable comes first)? Q2. Were the participants included in any comparisons similar? Q3. Were the participants included in any comparisons receiving 
Table 3. Main results of the eligible studies investigating urea levels.

\begin{tabular}{|c|c|c|c|c|c|c|c|c|}
\hline Authors & $\begin{array}{l}\text { Mean } \\
\text { Concentration } \\
\text { of SaU } \\
\text { predialysis in } \\
\mathrm{mmol} / \mathrm{L} \text { (SD) }\end{array}$ & $\begin{array}{c}\text { Mean } \\
\text { Concentration } \\
\text { of SaU } \\
\text { postdialysis (SD) }\end{array}$ & $\begin{array}{l}\text { Difference } \\
\text { (\%) }\end{array}$ & $\begin{array}{l}\text { Mean } \\
\text { concentration } \\
\text { of SU } \\
\text { predialysis in } \\
\mathrm{mmol} / \mathrm{L}(\mathrm{SD})\end{array}$ & $\begin{array}{c}\text { Mean } \\
\text { concentration } \\
\text { of SU } \\
\text { postdialysis in } \\
\mathrm{mmol} / \mathrm{L} \text { (SD) }\end{array}$ & $\begin{array}{l}\text { Difference } \\
\text { (\%) }\end{array}$ & $r$ & Conclusion \\
\hline $\begin{array}{l}\text { Cheng et al., } \\
2013^{23}\end{array}$ & $\begin{array}{c}28.33 \\
( \pm 7.53)\end{array}$ & $9.91( \pm 4.21)$ & 65 & $\begin{array}{c}28.54 \\
( \pm 5.85)\end{array}$ & $\begin{array}{c}10.57 \\
( \pm 4.22)\end{array}$ & 63 & 0.909 & $\begin{array}{l}\text { There was a strong } \\
\text { correlation }(r=0.90, \\
p<0.001) \text { between } \\
\text { blood urea and } \\
\text { salivary urea. }\end{array}$ \\
\hline $\begin{array}{l}\text { Seethalakshmi et al., } \\
2014^{24}\end{array}$ & $\begin{array}{c}15.85 \\
( \pm 4.99)\end{array}$ & $6.73( \pm 2.62)$ & 58 & $\begin{array}{c}22.03 \\
( \pm 5.46)\end{array}$ & $\begin{array}{c}8.52 \\
( \pm 2.69)\end{array}$ & 62 & * & $\begin{array}{l}\text { Urea levels in serum } \\
\text { and saliva were } \\
\text { significantly lower after } \\
\text { hemodialysis than } \\
\text { before hemodialysis. }\end{array}$ \\
\hline Chen et al., $2016^{25}$ & $\begin{array}{c}16.92 \\
( \pm 9.73)\end{array}$ & $5.94( \pm 3.48)$ & 65 & $\begin{array}{c}21.67 \\
( \pm 5.64)\end{array}$ & $\begin{array}{c}6.73 \\
( \pm 2.21)\end{array}$ & 69 & 0.77 & $\begin{array}{l}\text { There was a strong } \\
\text { correlation }(r=0.77, \\
p<0.001, n=69) \\
\text { between blood urea } \\
\text { and salivary urea. }\end{array}$ \\
\hline $\begin{array}{l}\text { Alpdemir et al., } \\
2018^{28}\end{array}$ & $\begin{array}{c}44.9 \\
( \pm 21.10)\end{array}$ & $\begin{array}{c}24.7 \\
( \pm 12.42)\end{array}$ & 45 & $\begin{array}{c}43.9 \\
( \pm 14.96)\end{array}$ & $\begin{array}{c}14.8 \\
( \pm 7.78)\end{array}$ & 66 & 0.58 & $\begin{array}{l}\text { Urea levels in serum } \\
\text { and saliva were } \\
\text { significantly lower after } \\
\text { hemodialysis than } \\
\text { before hemodialysis } \\
(p<0.001) . \\
\text { This study showed a } \\
\text { moderate correlation } \\
(r=0.58, p<0.001) \\
\text { between blood and } \\
\text { salivary urea. }\end{array}$ \\
\hline $\begin{array}{l}\text { Bilancio et al., } \\
2018^{27}\end{array}$ & $\begin{array}{c}24.6 \\
( \pm 5.52)\end{array}$ & $7.8( \pm 2.28)$ & 68 & $\begin{array}{c}23.2 \\
( \pm 1.30)\end{array}$ & $\begin{array}{c}6.4 \\
( \pm 1.51)\end{array}$ & 72 & 0.96 & $\begin{array}{c}\text { The changes in } \\
\text { saliva concentrations } \\
\text { paralleled the } \\
\text { changes in plasma } \\
\text { concentrations for urea. }\end{array}$ \\
\hline $\begin{array}{l}\text { Nogalcheva et al., } \\
2018^{26}\end{array}$ & 46.89 & $\begin{array}{c}46.78( \pm \\
23.47)\end{array}$ & 0.3 & 21.24 & 14.71 & 31 & a & $\begin{array}{l}\text { There was a statistically } \\
\text { significant reduction } \\
\text { in blood urea levels } \\
\text { before and after dialysis } \\
\text { ( } p=0.000) \text {. However, } \\
\text { there was no statistically } \\
\text { significant reduction } \\
\text { in salivary urea levels } \\
(p=0.240) \text {. }\end{array}$ \\
\hline
\end{tabular}

"Variable investigated by the author; SaU: salivary urea; SU: serum urea.

similar treatment/care, other than the exposure or intervention of interest? Q4. Was there a control group? Q5. Were there multiple measurements of the outcome both pre and post the intervention/ exposure? Q6. Was follow up complete and if not, were differences between groups in terms of their follow up adequately described and analyzed? Q7. Were the outcomes of participants included in any comparisons measured in the same way? Q8. Were outcomes measured in a reliable way?
Q9. Was appropriate statistical analysis used? $\sqrt{ }$ yes; $\times$ no; U: Unclear.

\section{Synthesis of results and meta-analysis}

Five studies were selected for quantitative assessment in at least one meta-analysis. Table 3 and Table 4 summarize all values of concentration, proportion differences, and the correlation $(r)$ used to perform meta-analysis for each outcome. The study by Nogalcheva et al. ${ }^{26}$ was not included in any meta- 
Table 4. Main results of the eligible studies investigating creatinine levels.

\begin{tabular}{|c|c|c|c|c|c|c|c|c|}
\hline Authors & $\begin{array}{l}\text { Mean } \\
\text { concentration } \\
\text { of } \mathrm{SaCr} \\
\text { predialysis in } \\
\mathrm{mg} / \mathrm{dL} \text { (SD) }\end{array}$ & $\begin{array}{c}\text { Mean } \\
\text { concentration } \\
\text { of } \mathrm{SaCr} \\
\text { postdialysis in } \\
\mathrm{mg} / \mathrm{dL} \text { (DS) }\end{array}$ & $\begin{array}{l}\text { Difference } \\
\text { (\%) }\end{array}$ & $\begin{array}{l}\text { Mean } \\
\text { concentration } \\
\text { of SCr } \\
\text { predialysis in } \\
\mathrm{mg} / \mathrm{dL} \text { (SD) }\end{array}$ & $\begin{array}{l}\text { Mean } \\
\text { concentration } \\
\text { of SCr } \\
\text { postdialysis in } \\
\mathrm{mg} / \mathrm{dL} \text { (SD) }\end{array}$ & $\begin{array}{l}\text { Difference } \\
\text { (\%) }\end{array}$ & $\begin{array}{l}\text { Correlation } \\
(r)\end{array}$ & Conclusion \\
\hline $\begin{array}{l}\text { Cheng et al., } \\
2013 .{ }^{23}\end{array}$ & $1.13( \pm 0.4)$ & $0.34( \pm 0.1)$ & 70 & $\begin{array}{c}11.28 \\
( \pm 1.98)\end{array}$ & $\begin{array}{c}4.01 \\
( \pm 1.48)\end{array}$ & 64 & 0.87 & $\begin{array}{l}\text { Creatinine levels in serum } \\
\text { and saliva were significantly } \\
\text { lower after hemodialysis than } \\
\text { before hemodialysis, and a } \\
\text { high correlation }(r=0.87, \\
p<0.01 \text { ) were observed } \\
\text { between blood and salivary } \\
\text { creatinine. }\end{array}$ \\
\hline $\begin{array}{l}\text { Seethalakshmi et al., } \\
2014 .{ }^{24}\end{array}$ & $\begin{array}{c}0.89 \\
( \pm 0.47)\end{array}$ & $\begin{array}{r}0.639 \\
( \pm 0.34)\end{array}$ & 29 & $\begin{array}{c}8.68 \\
( \pm 2.77)\end{array}$ & $\begin{array}{c}4.12 \\
( \pm 1.48)\end{array}$ & 53 & * & $\begin{array}{c}\text { Creatinine levels in serum } \\
\text { and saliva were significantly } \\
\text { lower after hemodialysis than } \\
\text { before hemodialysis. }\end{array}$ \\
\hline \multirow{2}{*}{$\begin{array}{l}\text { Alpdemir et al., } \\
2018 .{ }^{28}\end{array}$} & 0.66 & 0.43 & \multirow[t]{2}{*}{35} & \multirow{2}{*}{$\begin{array}{c}7.24 \\
( \pm 2.5)\end{array}$} & \multirow{2}{*}{$\begin{array}{c}2.99 \\
( \pm 1.06)\end{array}$} & \multirow[t]{2}{*}{59} & \multirow[t]{2}{*}{0.38} & $\begin{array}{l}\text { Creatinine levels in serum } \\
\text { and saliva were significantly } \\
\text { lower after hemodialysis } \\
\text { than before hemodialysis } \\
\qquad(p<0.001) \text {. }\end{array}$ \\
\hline & $( \pm 0.5)$ & $( \pm 0.23)$ & & & & & & $\begin{array}{l}\text { This study showed a low } \\
\text { correlation }(r=0.38 \\
p<0.001) \text { between blood } \\
\text { and salivary creatinine. }\end{array}$ \\
\hline $\begin{array}{l}\text { Nogalcheva et al., } \\
2018 .^{26}\end{array}$ & 0.6363 & 0.6343 & 0.4 & 8.31 & 4.02 & 52 & * & $\begin{array}{l}\text { There was a statistically } \\
\text { significant reduction in } \\
\text { blood creatinine levels } \\
\text { before and after dialysis } \\
\text { ( } p=0.000) \text {. However, there } \\
\text { was no statistically significant } \\
\text { reduction in salivary } \\
\text { creatinine levels ( } p=0.065) \text {. }\end{array}$ \\
\hline
\end{tabular}

"The authors did not perform this analysis; SaCr: salivary creatinine; SCr: serum creatinine.

Table 5. Risk of bias assessed by the Joanna Briggs Institute Critical Appraisal Tools for use in JBI Systematic Reviews for Quasiexperimental studies.

\begin{tabular}{|c|c|c|c|c|c|c|c|c|c|c|}
\hline Authors & Q.1 & Q.2 & Q.3 & Q.4 & Q.5 & Q.6 & Q.7 & Q.8 & Q.9 & $\%$ yes/risk \\
\hline Cheng et al., $2013^{23}$ & $\sqrt{ }$ & $\sqrt{ }$ & $\sqrt{ }$ & $x$ & U & $\mathrm{N} / \mathrm{A}$ & $\checkmark$ & $\sqrt{ }$ & $\sqrt{ }$ & $75 \% /$ low risk \\
\hline Seethalakshmi et al., $2014 .{ }^{24}$ & $\sqrt{ }$ & $\sqrt{ }$ & $\checkmark$ & $x$ & $U$ & $\mathrm{~N} / \mathrm{A}$ & $\sqrt{ }$ & $\sqrt{ }$ & $\sqrt{ }$ & $75 \% /$ low risk \\
\hline Chen et al., $2016^{25}$ & $\sqrt{ }$ & $\sqrt{ }$ & $\sqrt{ }$ & $x$ & $U$ & $\mathrm{~N} / \mathrm{A}$ & $\sqrt{ }$ & $\sqrt{ }$ & $\sqrt{ }$ & $75 \% /$ low risk \\
\hline Alpdemir et al., $2018^{28}$ & $\sqrt{ }$ & $\sqrt{ }$ & $\sqrt{ }$ & $\sqrt{ }$ & U & $\mathrm{N} / \mathrm{A}$ & $\sqrt{ }$ & $\sqrt{ }$ & $\sqrt{ }$ & $88 \% /$ low risk \\
\hline Bilancio et al., $2018^{27}$ & $\sqrt{ }$ & $\sqrt{ }$ & $\sqrt{ }$ & $\sqrt{ }$ & $U$ & $\mathrm{~N} / \mathrm{A}$ & $\checkmark$ & $\sqrt{ }$ & $\sqrt{ }$ & $88 \% /$ low risk \\
\hline Nogalcheva et al., $2018^{26}$ & $\sqrt{ }$ & $\sqrt{ }$ & $\sqrt{ }$ & $x$ & U & $\mathrm{N} / \mathrm{A}$ & $\sqrt{ }$ & $\sqrt{ }$ & $\sqrt{ }$ & $75 \% /$ low risk \\
\hline
\end{tabular}

analysis since it did not present standard deviation values to calculate standard errors for differences properly or the correlation coefficient (r).

Bioproducts from salivary samples showed different magnitudes of correlation. Urea collected from saliva was similar to the serum values. According to the pooled correlation coefficient from the meta-analysis of urea correlation, there is a high correlation value (r: 0.79; 95\%CI: 0.56-1.00). Only two studies showed data for creatinine correlation, presenting moderate correlation with high confidence interval (r: 0.64; 95\%CI: 0.16-1.00). Data from all estimated correlation coefficients are presented in Figure 2. 


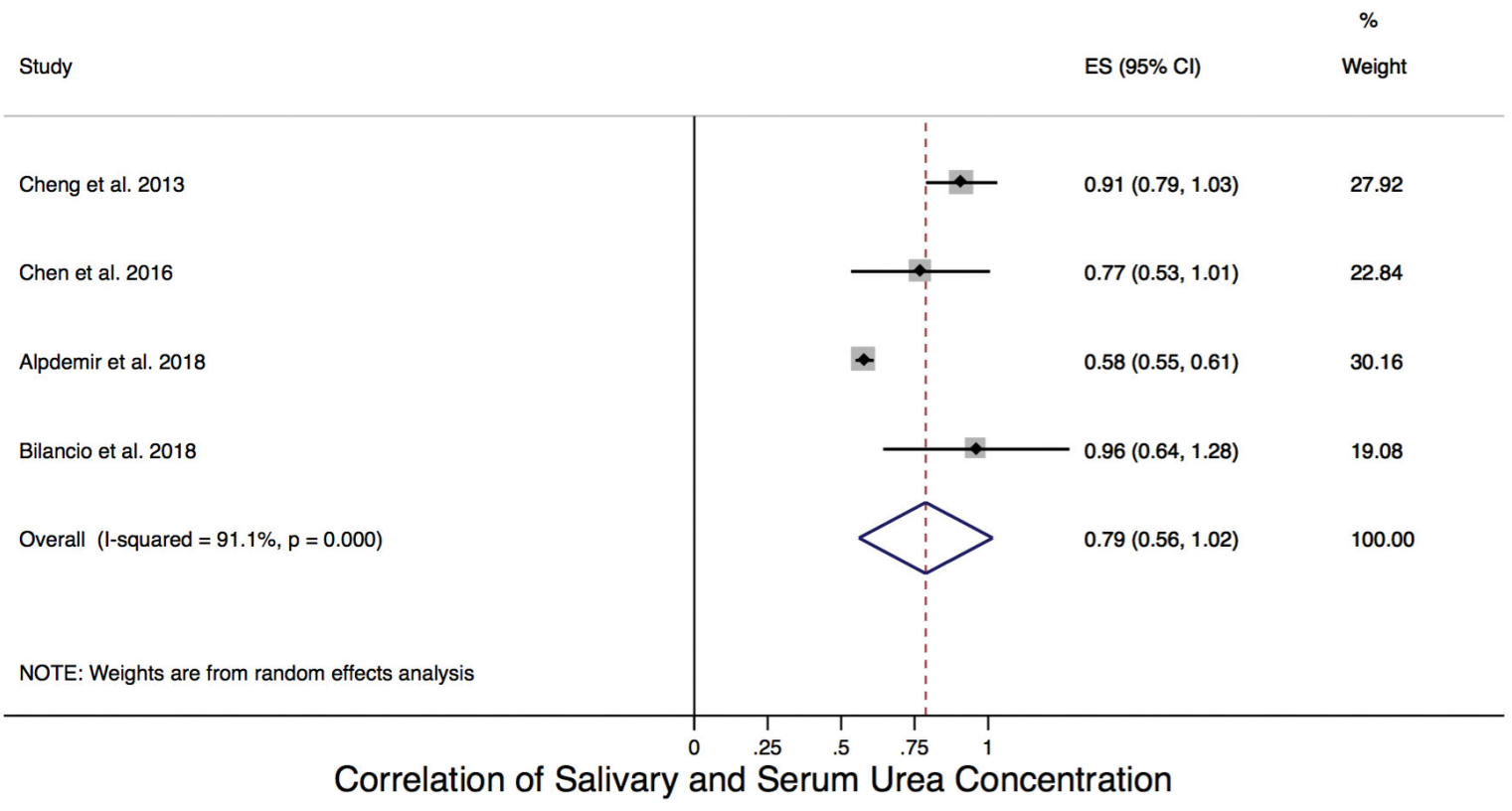

Figure 2A. Forest plot of the correlation between salivary and serum urea concentration. Weights are from random effects analysis.

The mean difference and proportion differences subgroup meta-analysis and the meta-regression did not show significant differences between salivary and serum differences in renal function indicators from pre- to posthemodialysis. When urea concentration reduction was analyzed, ${ }^{23,24,25,27,28}$ the serum urea values showed a standardized mean difference $(\mathrm{g})$ of $3.37 \mathrm{mmol} / \mathrm{L}$ (g; 3.00; 95\%CI: 2.25-4.50), which was greater than that of the salivary values (g: 1.95 ; 95\%CI: 2.14--0.81). However, there were no significant differences between serum and salivary values. The meta-regression analysis did not show statistical significance $(p=0.157)$; thus, the source of bioproducts did not explain possible heterogeneity in mean concentration reduction. Moreover, the same pattern was observed for the percentage reduction, considering the pooled reduction of $65.6 \%$ (95\%CI: $57.7-73.6)$ for serum and 58.6\% (95\%CI: 49.3-67.8) for salivary urea concentration pre- to posthemodialysis. The meta-regression analysis also did not show statistical significance $(p=0.251)$. Figure 3 shows all estimates of urea indicators of renal function considering the salivary and serum samples of each study.

Only three studies ${ }^{23,24,28}$ allowed for proper calculation of the salivary and serum mean concentrations and the subsequent standard errors for creatinine estimates. The results of salivary and serum creatinine mean and proportion reductions were even more similar than urea, and there was no difference in either $g$ or the percentage of reduction between pre-and posthemodialysis results. The salivary $g$ reduction of creatinine concentration was 0.56 (g: 0.56; 95\%CI: 0.03-1.08), and serum values presented almost the same reduction at 0.58 (g: 0.58; 95\%CI: -2.28-6.02). There was no statistical significance in the meta-regression as well ( $p=0.571)$. Considering the proportion of reduction, a higher value was evident in serum reduction (60.7\%; 95\%CI: 51.3-70.1) than in saliva (45.4\%; 95\%CI: 18.2-72.6) but was not a significant difference. In agreement, meta-regression analysis showed no statistical significance $(p=0.405)$. Figure 4 shows the summary of the meta-analysis for creatinine concentration and proportion differences.

\section{Certainty of identified evidence}

The GRADE approach ${ }^{20}$ was used to assess the certainty of the summary evidence of the correlation of salivary and serum levels of urea and creatinine (Table 6). Both summary estimates presented a very low level of certainty. The analysis of the certainty of evidence started as "low" because it only included 


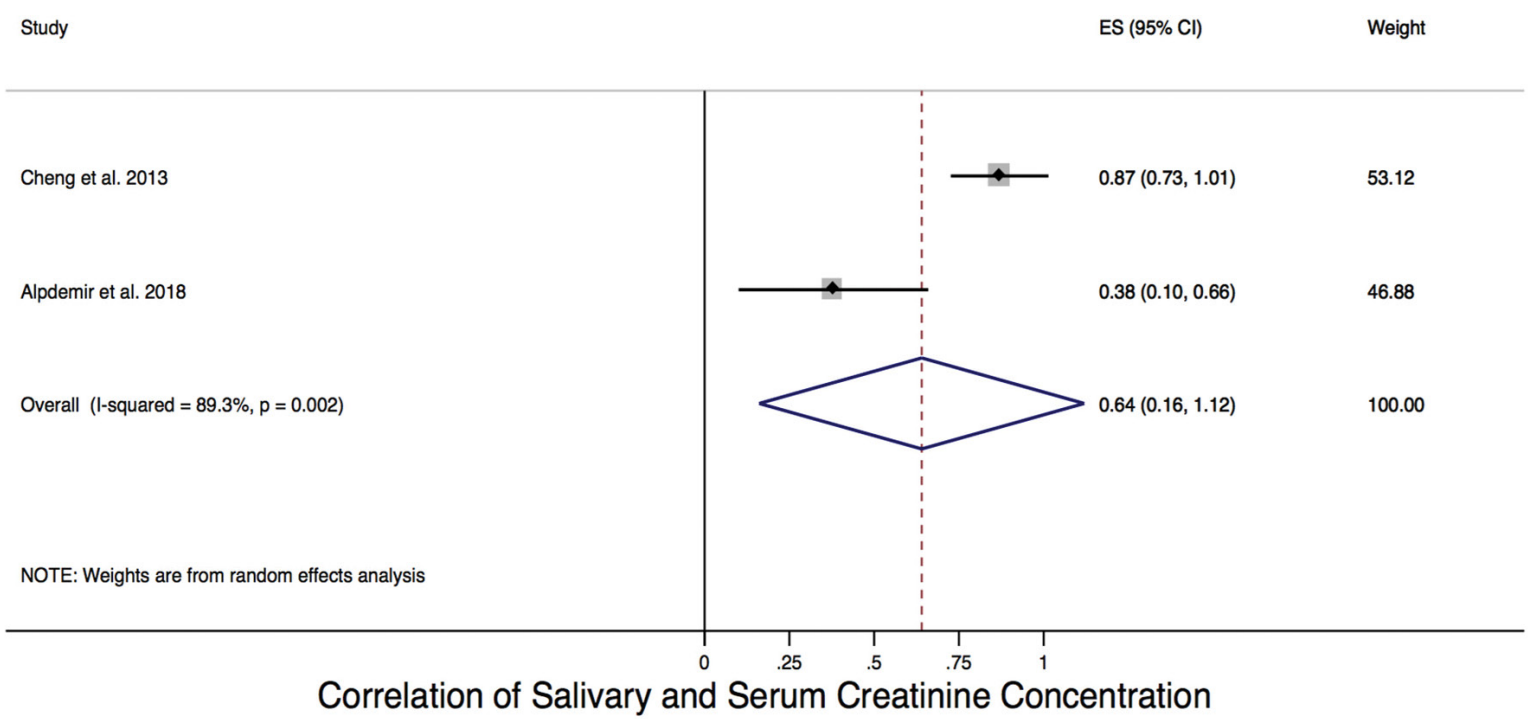

Figure 2B. Forest plot of the correlation between salivary and serum creatinine concentrations. Weights are from random effects analysis.

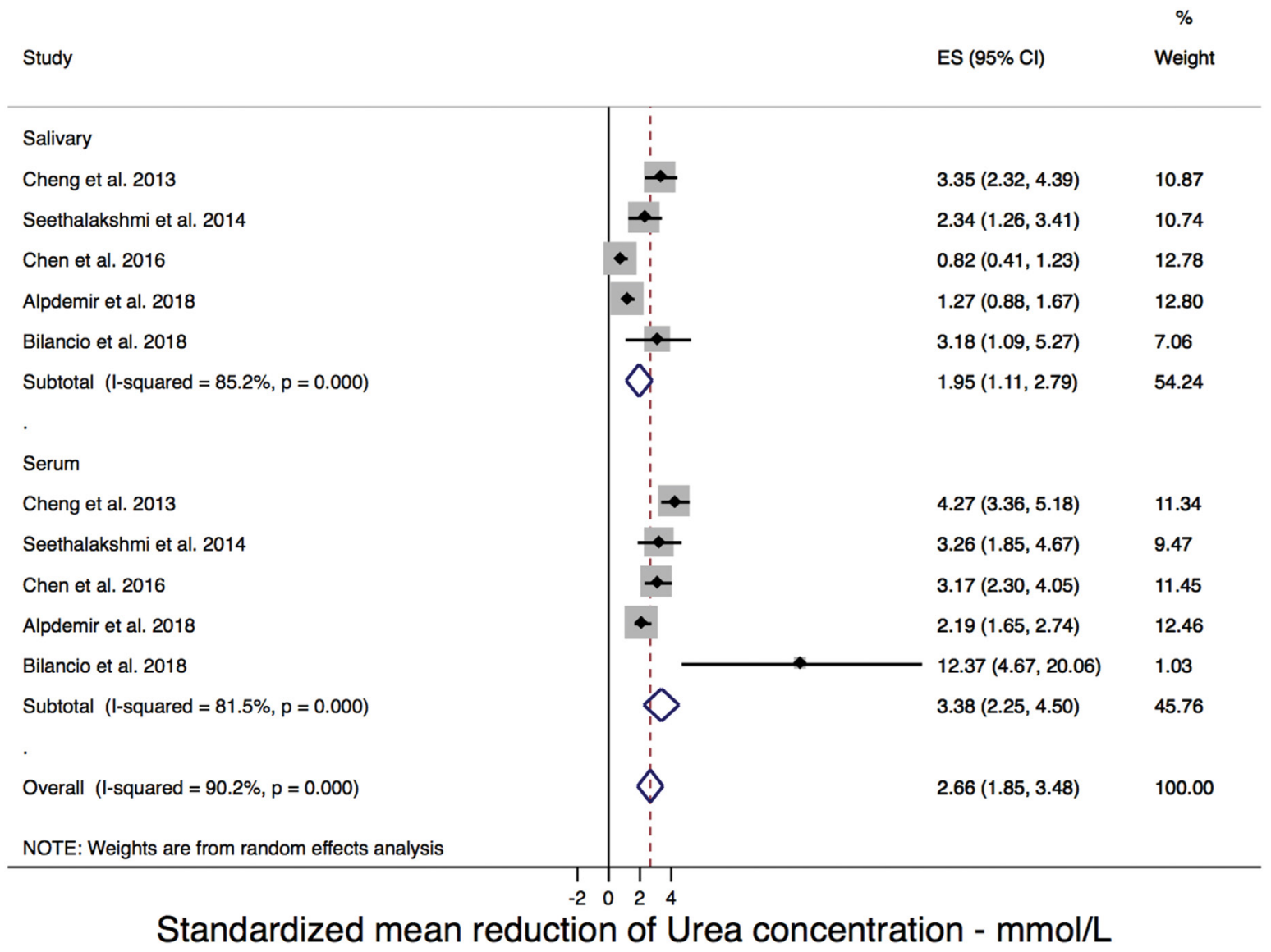

Figure 3A. Forest plot of the difference in urea concentrations from pre- to posthemodialysis meta-analysis of Hedges standard mean difference $(\mathrm{g})$ of urea concentration. Weights are from random effects analysis. 


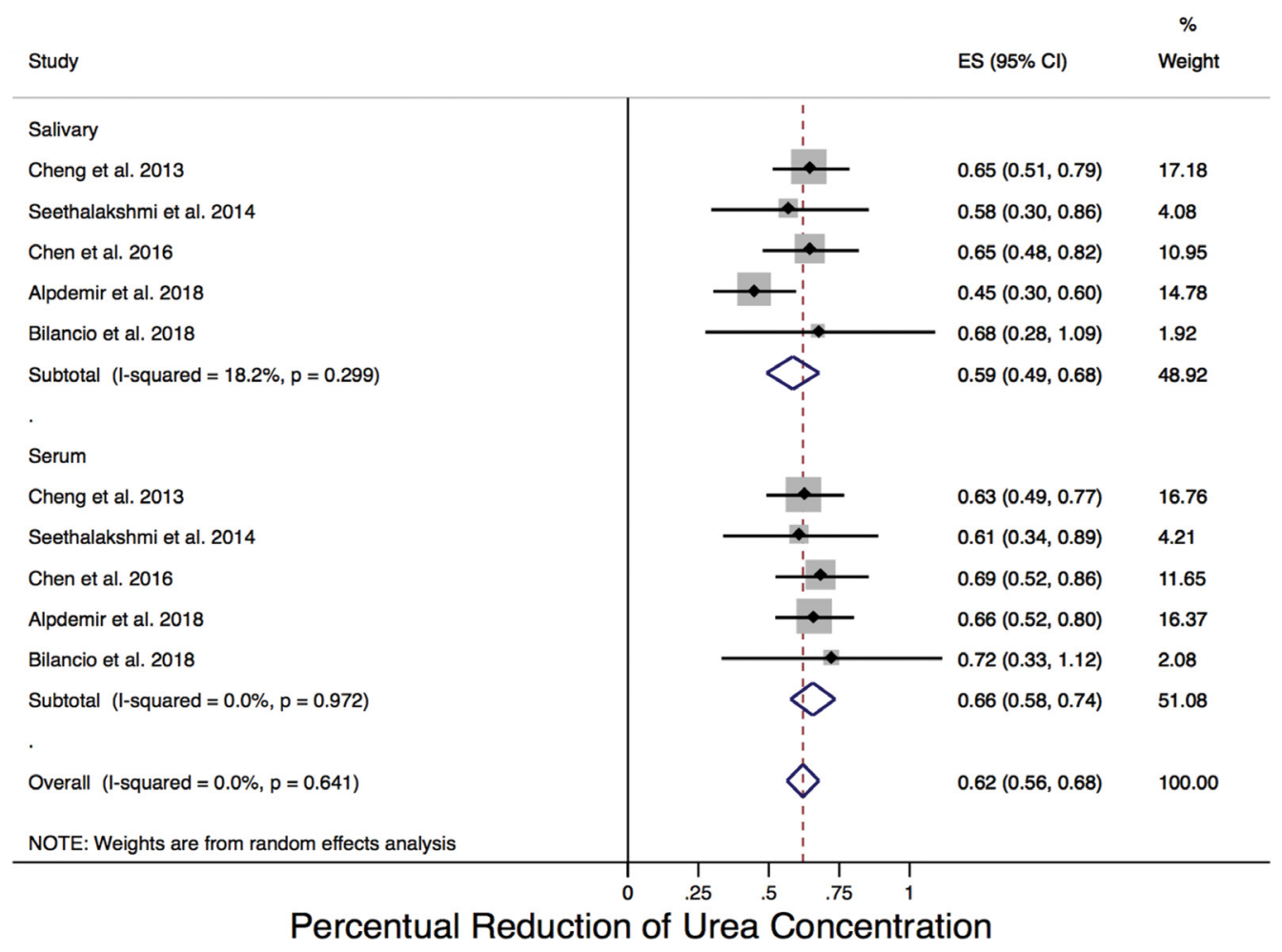

Figure 3B. Forest plot of the subgroup meta-analysis of the percentage reduction of urea concentration from pre- to posthemodialysis. Weights are from fixed effects analysis.

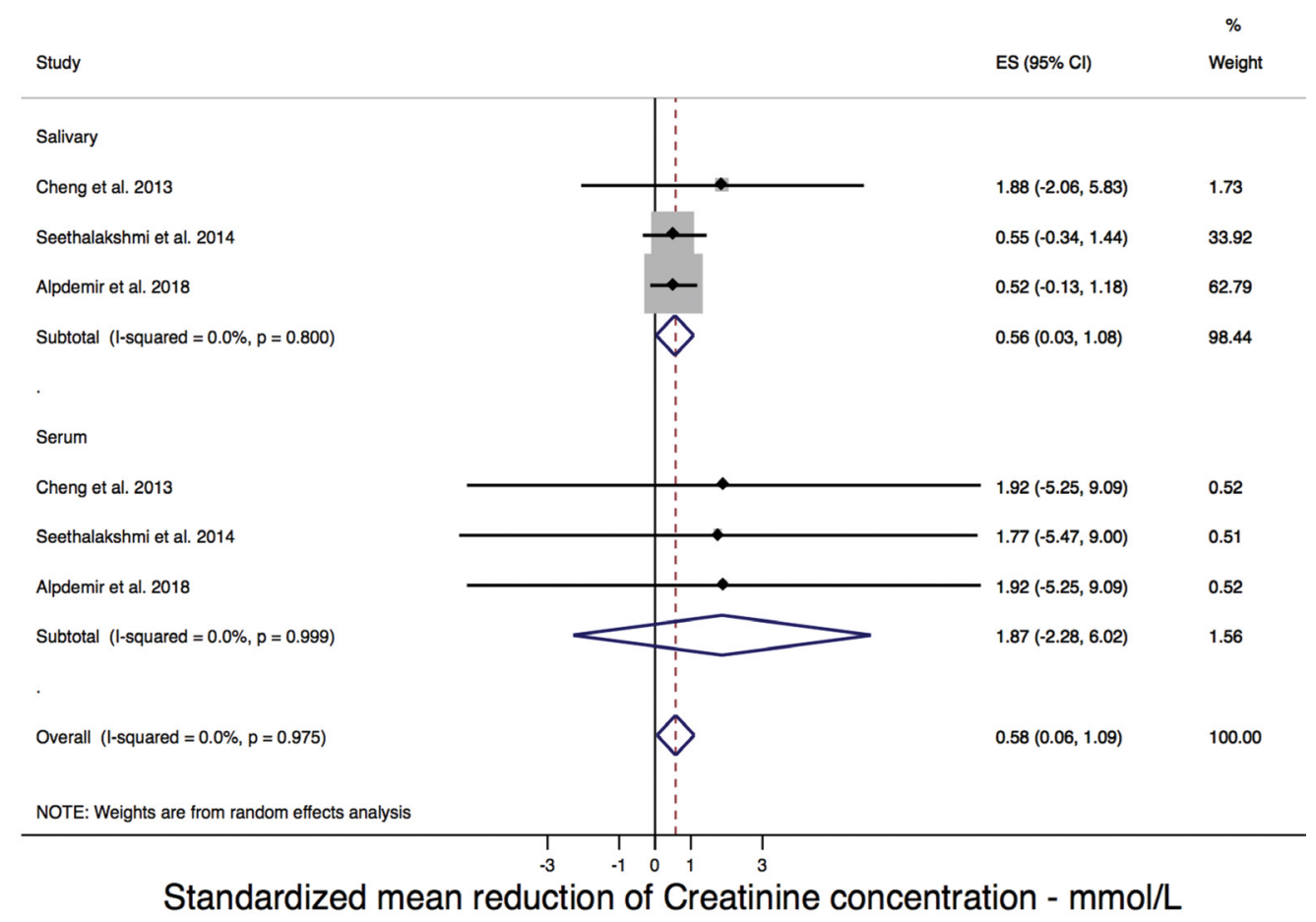

Figure 4A. Forest plot of the subgroup meta-analysis of Hedges standard mean difference $(\mathrm{g})$ of creatinine concentration from pre- to posthemodialysis. Weights are from random effects analysis. 


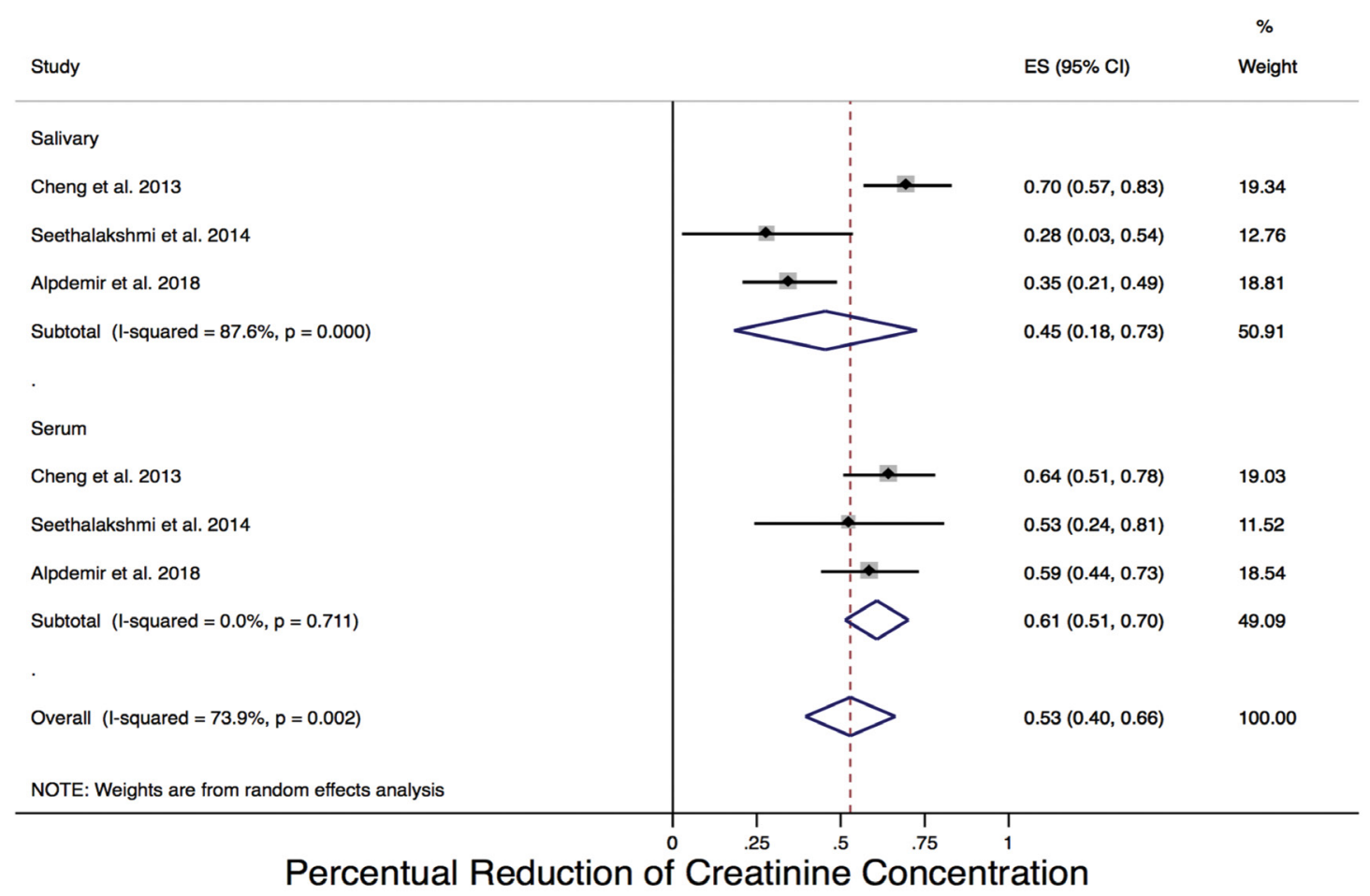

Figure 4B. Forest plot of the subgroup meta-analysis of the percentage reduction of creatinine concentration from pre- to posthemodialysis. Weights are from fixed effects analysis.

Table 6. Grading of Recommendations Assessment, Development, and Evaluation (GRADE) Summary of Findings Table for the Outcomes of the Systematic Review and Meta-Analysis.

\begin{tabular}{|c|c|c|c|c|c|c|c|c|c|c|}
\hline \multicolumn{7}{|c|}{ Quality Assessment } & \multicolumn{3}{|c|}{ Summary of Results } & \multirow[b]{2}{*}{ Importance } \\
\hline $\begin{array}{l}\text { Number } \\
\text { of studies }\end{array}$ & Study design & $\begin{array}{l}\text { Methodological } \\
\text { limitations }\end{array}$ & Inconsistency & Indirectness & Imprecision & $\begin{array}{c}\text { Publication } \\
\text { biases }\end{array}$ & $\begin{array}{l}\text { Number of } \\
\text { participants }\end{array}$ & Effect & $\begin{array}{l}\text { General } \\
\text { quality }\end{array}$ & \\
\hline \multicolumn{11}{|c|}{ Outcome 1: Correlation between saliva and serum - Urea levels } \\
\hline 4 & $\begin{array}{c}\text { pretest-posttest } \\
\text { studies }\end{array}$ & Not serious ${ }^{a}$ & Serious ${ }^{b}$ & $\begin{array}{c}\text { Not } \\
\text { serious }^{c}\end{array}$ & $\begin{array}{c}\text { Very } \\
\text { serious }^{d}\end{array}$ & none & 152 & $\begin{array}{c}r: 0.79 \\
(95 \% \mathrm{Cl}: \\
0.56-1.00)\end{array}$ & $\begin{array}{c}\oplus \\
\text { VERY } \\
\text { LOW }\end{array}$ & Critical \\
\hline \multicolumn{11}{|c|}{ Outcome 2: Correlation between saliva and serum - Creatinine levels } \\
\hline 2 & $\begin{array}{l}\text { pretest-posttest } \\
\text { studies }\end{array}$ & Not serious ${ }^{a}$ & Serious ${ }^{b}$ & $\begin{array}{c}\text { Not } \\
\text { serious }\end{array}$ & $\begin{array}{c}\text { Very } \\
\text { serious }^{d}\end{array}$ & none & 135 & $\begin{array}{c}r: 0.64 \\
(95 \% \mathrm{Cl}: \\
0.16-1.00)\end{array}$ & $\begin{array}{c}\oplus \\
\text { VERY } \\
\text { LOW }\end{array}$ & Critical \\
\hline
\end{tabular}

a: All studies presented a low risk of bias; b: The $\mathrm{l}^{2}$ was high (> 75\%) - Downgraded by one level; c: Evidence came from studies with populations suitable for PICO; $d$ : The total number of participants is less than 400 , and there is a wide confidence interval in the effect estimates - Downgraded by two levels.

GRADE Working Group grades of evidence; High certainty: We are very confident that the true effect lies close to that of the estimate of the effect; Moderate certainty: We are moderately confident in the effect estimate: The true effect is likely to be close to the estimate of the effect, but there is a possibility that it is substantially different; Low certainty: Our confidence in the effect estimate is limited: The true effect may be substantially different from the estimate of the effect; Very low certainty: We have very little confidence in the effect estimate: The true effect is likely to be substantially different from the estimate of effect

observational studies. Subsequently, inconsistency and imprecision downgraded the certainty by one and two levels, respectively. Inconsistency was judged by the $\mathrm{I}^{2}$ test of each analysis, and the imprecision was judged by the number of participants and by the confidence interval of the estimates. 


\section{Discussion}

This systematic literature review aimed to investigate the use of salivary components for monitoring the efficacy of hemodialysis in chronic kidney disease (CKD) patients. The meta-analysis results confirmed a reduction in urea and creatinine salivary indicators from pre- to posthemodialysis. Despite saliva not presenting the same magnitude of the reduction observed in serum measures, there was no significant difference between the two approaches.

Hemodialysis is a procedure indicated for patients with glomerular filtration rate (GFR) lower than $15 \mathrm{ml} / \mathrm{min} / 1.73 \mathrm{~m}^{2},{ }^{29}$ in which the excess of metabolic products in the blood is filtered by diffusion through a superpermeable membrane, simulating an artificial kidney. ${ }^{1}$ Controlling the efficacy of the procedure is crucial, considering that it is essential to ensure the quality of life of individuals with renal impairment. In the present review, the efficacy of hemodialysis was assessed with creatinine and urea indicators pre- and posthemodialysis, as suggested in the literature. ${ }^{1}$ All eligible studies ${ }^{23,24,25,26,27,28}$ showed a significant reduction in urea and creatinine levels in both blood and saliva after hemodialysis, reinforcing the importance of this procedure for controlling the signs and symptoms of CKD patients.

Urea is a nitrogenated organic compound produced from the oxidation of amino acids, especially in the liver. ${ }^{30}$ The normal rates of urea in the blood and saliva are $30-40 \mathrm{mg} / \mathrm{dL}$ and $12-70 \mathrm{mg} / \mathrm{dL}$, respectively, and these values are used as an indirect form of assessing renal function. ${ }^{4}$ Several studies observed a positive correlation between blood and salivary urea indicators, in which increased levels of urea in the blood were also high in saliva. ${ }^{8,31,32}$ The present meta-analysis showed a significant reduction in urea indicators in both saliva (g: -1.45; 95\%CI: -2.14--0.81) and blood (g: -3.00; 95\%CI: -4.12--1.88), without a significant difference between them. This means that the reduction of urea molecules in the blood is similar to the reduction of urea in saliva. Additionally, the meta-analysis showed a high correlation value between salivary and serum levels of urea. These results may be explained by the molecular correlation that exists between these fluids. Urea is a molecule of small size and low weight, and it easily passes through the intercellular junctions of salivary glands by passive diffusion. ${ }^{33}$ Thus, once the concentration of urea in the blood decreases, fewer urea molecules are filtered to saliva, consequently reducing the levels of salivary urea.

However, urea indicators may be modified by bacteria related to dental caries and periodontitis, as well as enzymes present in saliva (arginase and urease), which degrade urea in ammonia $\left(\mathrm{NH}_{3}\right){ }^{34}$ This is common in CKD patients ${ }^{27}$ and consequently masks the actual levels of urea in saliva. Thus, assessing the amount of $\mathrm{NH}_{3}$ in the breath of chronic renal patients under hemodialysis may be a complementary tool for assessing the levels of salivary urea.

Creatinine levels are used to determine the GFR; these levels are high in patients with $C K D$, indicating a lowered GFR. ${ }^{1}$ Similar to the results obtained for urea, the present meta-analysis showed a reduction in creatinine levels posthemodialysis in saliva and blood, with moderate correlation between them. Although the reduction in creatinine in blood levels was more extensive than that in salivary levels, the meta-regression did not find significant differences between the fluids, indicating that the reduction of creatinine molecules in the blood is similar to the reduction in saliva. A potential explanation for the reduction in salivary indicators is that after hemodialysis, the blood creatinine indicators are reduced, and there is not a concentration gradient that positively affects the diffusion of creatinine molecules from blood to saliva, decreasing the passage of creatinine to the salivary flow. ${ }^{35}$

Although all of the eligible studies ${ }^{23,24,25,26,27,28}$ presented a low risk of bias, some limitations may explain the heterogeneity obtained in the metaanalysis. First, there was a lack of detailed data for the included patients, such as age, race, sex, and other systemic diseases associated with CKD. Moreover, the eligible studies ${ }^{23,24,25,26,27,28}$ did not precisely confirm the GFR of the patient when comparing blood and saliva; the GFR may interfere directly with creatinine and urea indicators and with the effects of hemodialysis.

Nonetheless, this is the first systematic review of the literature that observed the potential use of salivary biomarkers as a tool for monitoring the 
efficacy of hemodialysis in chronic renal patients. The meta-analysis of the data obtained from the studies also represents a strength of this review, as it provides greater consistency with the results obtained. Moreover, the extensive search in different databases, without restricting the year and using the "grey literature", significantly minimizes the risk of bias in the study selection. Using the GRADE approach ${ }^{20}$ and The Joanna Briggs Institute Critical Appraisal tools to assess the certainty of the summary evidence and the methodological quality of the studies, respectively, shows the rigor of data collection of the eligible studies.

According to Dawes and Siqueira, ${ }^{36}$ many plasma proteins enter saliva via gingival crevicular fluid, and for this reason, saliva can be considered an important tool for monitoring patients with CKD. We find strong support for our hypothesis, since the amount of urea and creatinine in saliva and plasma were measured in healthy patients and CKD patients before and after dialysis. The amounts of urea $(\mathrm{mmol} / \mathrm{L})$ and creatinine $(\mu \mathrm{mol} / \mathrm{l})$ in serum were $13.8 \pm 3.25$, $43.9 \pm 14.96,14.8 \pm 7.78$ and $85.7 \pm 14.14,640.1 \pm 221.88$, and $252.2 \pm 94.58$ for the control group before and after hemodialysis, respectively. In addition, the amounts of urea $(\mathrm{mmol} / \mathrm{L})$ and creatinine $(\mathrm{mmol} / \mathrm{l})$ in saliva were $21.1 \pm 11.21 ; 44.9 \pm 21.10 ; 27.4 \pm 12.42$ and $37.2 \pm 26.52 ; 58.4 \pm 45.08$ and $38.1 \pm 21.21$ for the control group before and after hemodialysis, respectively. Even with the presence of proteases in the oral cavity, the relative difference between the groups shows that salivary urea and creatinine are abundant and that saliva testing may be valuable in CKD patient follow-up. In addition, when comparing salivary creatinine and urea concentrations with their concentration in blood, our previous study described a sensitivity of $93.3 \%$ (95\%CI: 88.6-97.9) for salivary creatinine levels and $87.5 \%$ (95\%CI: 83.2-91.8) for salivary urea levels, while the overall specificity was $87.1 \%$ (95\%CI: $82.8-91.3$ ) and $83.2 \%$ (95\%CI: 65.0-101.4) for salivary creatinine and urea levels, respectively. ${ }^{12}$ Another factor that should be analyzed is the absence of data related to the oral health of the study participants, considering that the presence of oral diseases may interfere with the biomarker values analyzed.
The results from this meta-analysis reaffirm the role of saliva as a promising tool for monitoring patients in advanced stages of CKD. Patients with kidney diseases require constant and regular follow-ups and may require lifelong treatment. According to the National Kidney Foundation, CKD can be divided into 5 stages (1-kidney damage with normal or increased GFR to 5- kidney failure). Stage 5 patients are treated with hemodialysis; however, for patients between stages 1 and 4, very close follow-up is required to estimate the disease progression and for evaluation and treatment plans for possible complications. One of the treatments for patients in level 4 is peritoneal dialysis, which can be performed at home. Thus, replacing blood collection with saliva collection to verify urea and creatinine levels may be beneficial in countless aspects, such as cost reduction, easy at-home collection, and decreased patient anxiety. Additionally, the literature reports that patients with CKD have a higher flow rate after hemodialysis $(0.8 \mathrm{~mL} / \mathrm{min})$ compared to $(0.4 \mathrm{~mL} / \mathrm{min})$ prior to hemodialysis, but despite this hyposalivation scenario, saliva is still considered an alternative method for CKD patient follow-up. ${ }^{4}$ Additionally, given that saliva collection is a less invasive method for collecting biological material than blood collection, using saliva would decrease the risk of infection to which patients are exposed during blood collection; this is positive, keeping in mind that the immunity of these patients is often low due to renal problems potentially presenting secondary diseases.

Thus, the present study provides relevant and essential information that opens avenues for further studies to be performed with greater methodological rigor to adjust the GRF equation to validate the use of saliva as a diagnostic tool and as a monitoring method for kidney disease patients.

\section{Limitations}

This study is not free of limitations. The first limitation is the low number of studies included in the meta-analysis. Additionally, the included studies showed a high level of heterogeneity caused mainly by the lack of standardization in the assessment of results. Another limitation in this review is the general quality of the evidence found. According to 
the GRADE approach, ${ }^{20}$ the summary estimates had a very low level of certainty. This is primarily due to the design of the studies included, considering observational studies already start at lower levels. Second, the strong inconsistencies observed among the studies for each outcome and the wide confidence interval of the summary estimates downgraded the certainty of evidence by two levels. Thus, these results should be interpreted with caution, and more studies should be performed in the future.

Thus, despite the promising results, they should be analyzed with caution, and further studies with an improved design (diagnostic accuracy studies) are required to confirm the use of saliva as a tool for monitoring the efficacy of hemodialysis in CKD patients and to validate a mathematical formula that establishes the GFR through saliva.

\section{Conclusion}

There is a reduction in salivary urea and creatinine levels in comparison to the reduction found in the blood after hemodialysis in chronic kidney disease patients. As a clinical outcome, the present study provides relevant and essential information that could serve as a basis for an innovative study to be performed with greater methodological rigor to adjust the glomerular filtration rate (GRF) equation to validate the use of saliva as a diagnostic tool and follow-up method for kidney disease patients.

\section{References}

1. Vadakedath S, Kandi V. Dialysis: a review of the mechanisms underlying complications in the management of chronic renal failure. Cureus. 2017 Aug;9(8):e1603. https://doi.org/10.7759/cureus.1603

2. Himmelfarb J, Ikizler TA. Hemodialysis. N Engl J Med. 2010 Nov;363(19):1833-45. https://doi.org/10.1056/NEJMra0902710

3. Xing $X$, Shi $X$, Zhang M, Jin W, Ye J. CE determination of creatinine and uric acid in saliva and urine during exercise. Chromatographia. 2008;67(11): 985-8. https://doi.org/10.1365/s10337-008-0599-1

4. Khanum N, Mysore-Shivalingu M, Basappa S, Patil A, Kanwar S. Evaluation of changes in salivary composition in renal failure patients before and after hemodialysis. J Clin Exp Dent. 2017 Nov;9(11):e1340-5. https://doi.org/10.4317/jced.54027

5. Chiappin S, Antonelli G, Gatti R, De Palo EF. Saliva specimen: a new laboratory tool for diagnostic and basic investigation. Clin Chim Acta. 2007 Aug;383(1-2):30-40. https://doi.org/10.1016/i.cca.2007.04.011

6. Yoshizawa JM, Schafer CA, Schafer JJ, Farrell JJ, Paster BJ, Wong DT. Salivary biomarkers: toward future clinical and diagnostic utilities. Clin Microbiol Rev. 2013 Oct;26(4):781-91. https://doi.org/10.1128/CMR.00021-13

7. Edey M, Barraclough K, Johnson DW. Review article: hepatitis B and dialysis. Nephrology (Carlton). 2010 Mar;15(2):137-45. https://doi.org/10.1111/j.1440-1797.2009.01268.x

8. Jones GR. Lim. EM. The National Kidney Foundation Guideline on estimation of the glomerular filtration rate. Clin Biochem Rev. 2003;24(3):95-8.

9. Gupta S, Nayak MT, Sunitha JD, Dawar G, Sinha N, Rallan NS. Correlation of salivary glucose level with blood glucose level in diabetes mellitus. J Oral Maxillofac Pathol. 2017 Sep-Dec;21(3):334-9. https://doi.org/10.4103/jomfp.JOMFP_222_15

10. Abdul Rehman S, Khurshid Z, Hussain Niazi F, Naseem M, Al Waddani H, Sahibzada HA, et al. Role of Salivary Biomarkers in Detection of Cardiovascular Diseases (CVD). Proteomes. 2017 Aug;5(3):E21. https://doi.org/10.3390/proteomes5030021

11. Pham TA. Validation of the salivary urea and creatinine tests as screening methods of chronic kidney disease in Vietnamese patients. Acta Odontol Scand. 2017 Nov;75(8):551-6. https://doi.org/10.1080/00016357.2017.1356467

12. Rodrigues RP, Vieira WA, Siqueira WL, Blumenberg C, Bernardino IM, Cardoso SV, et al. Saliva as an alternative to blood in the determination of uremic state in adult patients with chronic kidney disease: a systematic review and meta-analysis [published online ahead of print, 2020 May 23]. Clin Oral Investig. 2020 Jul;24(7):2203-17. https://doi.org/10.1007/s00784-020-03340-2

13. Moher D, Shamseer L, Clarke M, Ghersi D, Liberati A, Petticrew M, et al. Preferred reporting items for systematic review and meta-analysis protocols (PRISMA-P) 2015 statement. Syst Rev. 2015 Jan;4(1):1. https://doi.org/10.1186/2046-4053-4-1

14. Aromataris E, Munn Z, editors. JBI Manual for evidence synthesis. 2020 [cited 2019 August 24]. Available from https://synthesismanual.jbi.global

15. Tufanaru C, Munn Z, Aromataris E, Campbell J, Hopp L. Systematic reviews of effectiveness. In: Aromataris E, Munn Z (Editors). JBI Manual for evidence synthesis. 2020 [cited 2019 August 30]. Available from: https://wiki.jbi.global/display/MANUAL/Chapter+3\%3A+S ystematic+reviews + of +effectiveness 
16. Harris AD, McGregor JC, Perencevich EN, Furuno JP, Zhu J, Peterson DE, et al. The use and interpretation of quasi-experimental studies in medical informatics. J Am Med Inform Assoc. 2006 Jan-Feb;13(1):16-23. https://doi.org/10.1197/jamia.M1749

17. Cuiipers P, Weitz E, Cristea IA, Twisk J. Pre-post effect sizes should be avoided in meta-analyses. Epidemiol Psychiatr Sci. 2017 Aug;26(4):364-8. https://doi.org/10.1017/S2045796016000809

18. Borenstein M, Hedges LV, Higgins JP. Introduction to meta-analysis. New York: JohnWiley \& Sons, Inc; 2009. https://doi.org/10.1002/9780470743386

19. DerSimonian R, Laird N. Meta-analysis in clinical trials revisited. Contemp Clin Trials. 2015 Nov;45(Pt A):139-45. https://doi.org/10.1016/i.cct.2015.09.002

20. Balshem H, Helfand M, Schünemann HJ, Oxman AD, Kunz R, Brozek J, et al. GRADE guidelines: 3. Rating the quality of evidence. J Clin Epidemiol. 2011 Apr;64(4):401-6. https://doi.org/10.1016/i.jclinepi.2010.07.015

21. Suzuki M, Furuhashi M, Sesoko S, Kosuge K, Maeda T, Todoroki K, et al. Determination of creatinine-related molecules in saliva by reversed-phase liquid chromatography with tandem mass spectrometry and the evaluation of hemodialysis in chronic kidney disease patients. Anal Chim Acta. 2016 Mar;911:92-9. https://doi.org/10.1016/i.aca.2016.01.032

22. Chen CC, Hsieh JC, Chao CH, Yang WS, Cheng HT, Chan CK, et al. Correlation between breath ammonia and blood urea nitrogen levels in chronic kidney disease and dialysis patients. J Breath Res. 2020 Apr;14(3):036002.; Epub ahead of print. https://doi.org/10.1088/1752-7163/ab728b

23. Cheng P, Xia Y, Peng C, Zhou Z. [Evaluation of dialysis in patients with end-stage renal disease by salivary urea, creatinine and uric acid]. Zhong Nan Da Xue Xue Bao Yi Xue Ban. 2013 Dec;38(12):1260-3. Chinese. https://doi.org/10.3969/i.issn.1672-7347.2013.12.009

24. Seethalakshmi C, Koteeswaran D, Chiranjeevi V. Correlation of serum and salivary biochemical parameters in end stage renal disease patients undergoing hemodialysis in pre and post-dialysis state. J Clin Diagn Res. 2014 Dec;8(12):CC12-4. https://doi.org/10.7860/JCDR/2014/10404.5306

25. Chen W, Laiho S, Vaittinen O, Halonen L, Ortiz F, Forsblom C, et al. Biochemical pathways of breath ammonia (NH3) generation in patients with end-stage renal disease undergoing hemodialysis. J Breath Res. 2016 Aug;10(3):036011. https://doi.org/10.1088/1752-7155/10/3/036011

26. Nogalcheva AN, Konstantinova D, Pechalova P. Salivary creatinine and urea in patients with end-stage chronic kidney disease could not be used as diagnostic biomarkers for the effectiveness of dialysis treatment. G Ital Nefrol. 2018 Dec;35(6): 2018 -vol6.

27. Bilancio G, Cavallo P, Lombardi C, Guarino E, Cozza V, Giordano F, et al. Salivary levels of phosphorus and urea as indices of their plasma levels in nephropathic patients. J Clin Lab Anal. 2018 Sep;32(7):e22449. https://doi.org/10.1002/jcla.22449

28. Alpdemir M, Eryilmaz M, Alpdemir MF, Topçu G, Azak A, Yücel D. Comparison of Widely Used Biochemical Analytes in the Serum and Saliva Samples of Dialysis Patients. J Med Biochem. 2018 Jul;37(3):346-54. https://doi.org/10.1515/jomb-2017-0056

29. Renal Association. Normal GFR. London; 2018 [cited 2019 Aug 28]. Available from: https://renal.org/information-resources/the-ukeckd-guide/normal-gfr

30. Walser M, Bodenlos LJ. Urea metabolism in man. J Clin Invest. 1959 Sep;38(9):1617-26. https://doi.org/10.1172/JCI103940

31. Cardoso EM, Arregger AL, Tumilasci OR, Elbert A, Contreras LN. Assessment of salivary urea as a less invasive alternative to serum determinations. Scand J Clin Lab Invest. 2009;69(3):330-4. https://doi.org/10.1080/00365510802588076

32. Bagalad BS, Mohankumar KP, Madhushankari GS, Donoghue M, Kuberappa PH. Diagnostic accuracy of salivary creatinine, urea, and potassium levels to assess dialysis need in renal failure patients. Dent Res J (Isfahan). 2017 Jan-Feb;14(1):13-8. https://doi.org/10.4103/1735-3327.201138

33. Vanholder R, Gryp T, Glorieux G. Urea and chronic kidney disease: the comeback of the century? (in uraemia research). Nephrol Dial Transplant. 2018 Jan;33(1):4-12. https://doi.org/10.1093/ndt/gfx039

34. Pacher P, Beckman JS, Liaudet L. Nitric oxide and peroxynitrite in health and disease. Physiol Rev. 2007 Jan;87(1):315-424. https://doi.org/10.1152/physrev.00029.2006

35. Celec P, Tóthová L', Šebeková K, Podracká L', Boor P. Salivary markers of kidney function - Potentials and limitations. Clin Chim Acta. 2016 Jan;453:28-37. https://doi.org/10.1016/i.cca.2015.11.028

36. Siqueira WL, Dawes C. The salivary proteome: challenges and perspectives. Proteomics Clin Appl. 2011 Dec;5(11-12):575-9. https://doi.org/10.1002/prca.201100046 